\title{
Robust Central Reduction of Amyloid- $\beta$ in Humans with an Orally Available, Non-Peptidic $\beta$-Secretase Inhibitor
}

\author{
Patrick C. May, ${ }^{1}$ Robert A. Dean, ${ }^{1}$ Stephen L. Lowe, ${ }^{2}$ Ferenc Martenyi, ${ }^{1}$ Scott M. Sheehan, ${ }^{1}$ Leonard N. Boggs, ${ }^{1}$ \\ Scott A. Monk, ${ }^{1}$ Brian M. Mathes, ${ }^{1}$ Dustin J. Mergott, ${ }^{1}$ Brian M. Watson, ${ }^{1}$ Stephanie L. Stout, ${ }^{1}$ David E. Timm, ${ }^{1}$ \\ Elizabeth Smith LaBell, ${ }^{1}$ Celedon R. Gonzales, ${ }^{1}$ Masako Nakano, ${ }^{3}$ Stanford S. Jhee, ${ }^{4}$ Mark Yen, ${ }^{4,5}$ Larry Ereshefsky, ${ }^{4,6}$ \\ Terry D. Lindstrom, ${ }^{1}$ David 0. Calligaro, ${ }^{1}$ Patrick J. Cocke, ${ }^{1}$ D. Greg Hall, ${ }^{1}$ Stuart Friedrich, ${ }^{1}$ Martin Citron, ${ }^{1}$ \\ and James E. Audia ${ }^{1}$ \\ ${ }^{1}$ Lilly Research Laboratories, Eli Lilly \& Co., Indianapolis, Indiana 46285, ${ }^{2}$ Lilly-National University of Singapore Centre for Clinical Pharmacology, \\ Singapore 117597, Singapore, ${ }^{3}$ Eli Lilly Japan, Kobe 651-0086 Japan, ${ }^{4}$ PAREXEL International Early Phase Los Angeles, Glendale, California 91206 , \\ ${ }^{5}$ California Clinical Trials Medical Group, Glendale, California 91206, and ${ }^{6}$ University of Texas Health Science Center, San Antonio, Texas 98284
}

According to the amyloid cascade hypothesis, cerebral deposition of amyloid- $\beta$ peptide (A $\beta$ ) is critical for Alzheimer's disease (AD) pathogenesis. $\mathrm{A} \beta$ generation is initiated when $\beta$-secretase (BACE1) cleaves the amyloid precursor protein. For more than a decade, BACE1 has been a prime target for designing drugs to prevent or treat AD. However, development of such agents has turned out to be extremely challenging, with major hurdles in cell penetration, oral bioavailability/metabolic clearance, and brain access. Using a fragment-based chemistry strategy, we have generated LY2811376 [(S)-4-(2,4-difluoro-5-pyrimidin-5-yl-phenyl)-4-methyl-5,6-dihydro$4 H$-[1,3]thiazin-2-ylamine], the first orally available non-peptidic BACE1 inhibitor that produces profound $\mathrm{A} \beta$-lowering effects in animals. The biomarker changes obtained in preclinical animal models translate into man at doses of LY2811376 that were safe and well tolerated in healthy volunteers. Prominent and long-lasting A $\beta$ reductions in lumbar CSF were measured after oral dosing of $30 \mathrm{or} 90 \mathrm{mg}$ of LY2811376. This represents the first translation of BACE1-driven biomarker changes in CNS from preclinical animal models to man. Because of toxicology findings identified in longer-term preclinical studies, this compound is no longer progressing in clinical development. However, BACE1 remains a viable target because the adverse effects reported here were recapitulated in LY2811376-treated BACE1 $\mathrm{KO}$ mice and thus are unrelated to BACE1 inhibition. The magnitude and duration of central A $\beta$ reduction obtainable with BACE1 inhibition positions this protease as a tractable small-molecule target through which to test the amyloid hypothesis in man.

\section{Introduction}

Alzheimer's disease (AD) is characterized by the generation, aggregation, and deposition of amyloid- $\beta$ peptide $(A \beta)$ in the brain. According to the amyloid cascade hypothesis, $A \beta$ initiates a neurodegenerative cascade as either a soluble oligomer or a major constituent of cerebral amyloid plaques (Hardy and Selkoe, 2002). A $\beta$ is generated from the membrane-spanning $\beta$-amyloid precursor protein (APP) by sequential endoproteolytic cleavages. First $\beta$-secretase cleaves APP at the $\mathrm{NH}_{2}$ terminus of $\mathrm{A} \beta$ to release sAPP $\beta$ and $\mathrm{C} 99$, a $\mathrm{COOH}$-terminal fragment that remains membrane bound. Then $\mathrm{C} 99$ is further processed by

Received July 17, 2011; revised Sept. 1, 2011; accepted Sept. 9, 2011.

Author contributions: P.C.M., R.A.D., S.L.L., F.M., S.M.S., D.E.T., T.D.L., D.O.C., P.J.C., M.C., and J.E.A. designed research;S.L.L., S.M.S., L.N.B., S.A.M., B.M.M., D.J.M., B.M.W., S.L.S., D.E.T., E.S.L., C.R.G., M.N., S.S.J., M.Y., L.E., and D.G.H. performed research; P.C.M., R.A.D., S.L.L., F.M., S.M.S., L.N.B., S.A.M., B.M.M., D.J.M., B.M.W., S.L.S., D.E.T., E.S.L., C.R.G., M.N., S.S.J., M.Y., L.E., T.D.L., D.O.C., P.J.C., D.G.H., S.F., M.C., and J.E.A. analyzed data; P.C.M., R.A.D., P.J.C., M.C., and J.E.A. wrote the paper.

This research was funded by Eli Lilly \& $C$.

S.S.J., M.Y., and L.E. are employees of PAREXEL. All other authors are or were employees of Eli Lilly \& Co..

Correspondence should be addressed to Dr. Martin Citron, Lilly Research Laboratories, Eli Lilly and Co., Lilly

Corporate Center, Indianapolis, IN 46285. E-mail: citronma@lilly.com.

J. E. Audia's present address: Constellation Pharmaceuticals, Cambridge, MA 02142.

DOI:10.1523/JNEUROSCI.3647-11.2011

Copyright $\odot 2011$ the authors $\quad 0270-6474 / 11 / 3116507-10 \$ 15.00 / 0$ $\gamma$-secretase to release various isoforms of $\mathrm{A} \beta$, of which $\mathrm{A} \beta_{42}$ appears most pathogenic (Younkin, 1995). Therefore, $\beta$-secretase is a prime target for the development of $\mathrm{A} \beta$-lowering therapeutics for the prevention and treatment of AD. Compared to $\gamma$-secretase inhibitor development, $\beta$-secretase is perceived to be a more promising target, given that its activity is conferred by a single transmembrane aspartic protease, BACE1 (Hussain et al., 1999; Sinha et al., 1999; Vassar et al., 1999; Yan et al., 1999; Lin et al., 2000), whose crystal structure was solved and published early on (Hong et al., 2000). Unlike targeted deletion of the PSEN-1 gene, which is embryonic lethal, BACE1 knock-outs are viable and fertile and initially were reported to be without a major phenotype (Cai et al., 2001; Luo et al., 2001; Roberds et al., 2001). Recent analyses of BACE1 KOs have revealed morphologic and functional deficits in BACE1 KOs and have introduced a level of caution but, in general, have not limited enthusiasm for developing BACE1 inhibitors. Overall, BACE1 has represented an attractive target for medicinal chemists across the pharmaceutical industry for more than a decade (Stachel, 2009), but progress has been slow. Despite impressive intrinsic potency, the compounds reported to date have struggled to produce in vivo, CNS pharmacodynamic (PD) effects under standard treatment protocols (Rajendran et al., 2008; Sankaranarayanan et al., 2009; Zhu et al., 2009; Malamas et al., 2010). Common limitations have included 
Table 1. Crystallographic data

\begin{tabular}{lc}
\hline Space group & $P 212121$ \\
Cell constants & $86.768 \times 90.786 \times 131.753 \AA^{3}$ \\
Resolution & $1.84 \AA$ \\
Unique reflections & $89,630(6,575)$ \\
Completeness & $100(99.9) \%$ \\
Multiplicity & $6.5(6.3)$ \\
$R_{\text {merge }}$ & $0.087(0.538)$ \\
Mn (l/sd) & $10.0(3.5)$ \\
$R_{\text {cryst }}$ & $0.191(0.251)$ \\
$R_{\text {free }}$ & $0.236(0.239)$ \\
RMSD bonds & $0.010 \AA$ \\
RMSD angles & $1.283^{\circ}$ \\
Mean $B$ value & $24.6 \AA^{2}$ \\
\hline
\end{tabular}

Crystallographic statistics are from REFMAC and SCALA. Values for the highest-resolution shell are in parentheses. $\mathrm{Mn}(\mathrm{I} / \mathrm{sd})$, Mean intensity divided by the mean SD; RMSD, root mean square deviation.

loss of potency in cellular systems, low oral bioavailability/high metabolic clearance, and inadequate access to the target compartment within the CNS, often driven by P-glycoprotein or other transport systems. High throughput screening (HTS) across the industry on a massive scale has produced few alternative options. Consequently, no BACE inhibitor has been reported to be in advanced clinical development to this point, and growing concerns have emerged regarding the tractability of the target as the basis for agents capable of producing a robust PD effect in the central compartment.

Here we report the generation of LY2811376, a potent druglike BACE1 inhibitor. Robust BACE1-mediated biomarker changes in APP cleavage products translated from preclinical animal models to humans treated with LY2811376. Although the clinical development of this molecule was discontinued as a result of nonclinical non-target-related pathology findings, these data provide critical support for BACE1 as a tractable target for smallmolecule intervention to test the amyloid hypothesis.

\section{Materials and Methods}

\section{Crystallography}

BACE1 crystals were prepared with minor modifications of previously described methods (Hong et al., 2000). Briefly, crystals were soaked with $2.5 \mathrm{~mm}$ compound and flash cooled in liquid nitrogen using glycerol as a cryoprotectant. $\mathrm{x}$-ray diffraction data were collected at 100,000 at the Advanced Photon Source beamline 31-ID and were integrated and scaled using MOSFLM version 6.2.6 and SCALA version 5.0, respectively (Collaborative Computational Project, Number 4, 1994). The BACE crystal structure was solved by molecular replacement and was subject to iterative cycles of restrained refinement using REFMAC version 5.2.0019 and model building with COOT version 0.5 (Emsley et al., 2010). Figures were produced using PyMOL version 1.1r1 (http://www.pymol.org/).

Use of the Advanced Photon Source at Argonne National Laboratory was supported by the U.S. Department of Energy, Office of Science, Office of Basic Energy Sciences, under Contract DE-AC0206CH11357. Use of the Lilly Research Laboratories Collaborative Access Team beamline at Sector 31 of the Advanced Photon Source was provided by Eli Lilly \& Co., who operates the facility. See Table 1 for crystallographic data.

\section{Recombinant human BACE1 assays}

Human BACE1 was cloned, expressed, and purified essentially as described by Yang et al. (2004) and assayed using a synthetic peptide in a FRET format or using a MBP-C125Swe polypeptide substrate assay essentially as described by Yang et al. (2004) or Sinha et al. (1999), respectively.

\section{Aspartyl protease selectivity enzyme assays}

Human BACE2 was cloned, expressed, and purified essentially as described by Yang et al. (2004). The MBP-C125Swe assay was con- ducted essentially as described by Sinha et al. (1999). The 7-methoxycoumarin-4-yl-acetyl (mca) FRET assay for BACE2 was conducted essentially as described by Yang et al. (2004). Human liver cathepsin D was purchased from Calbiochem (catalog \#219041) and used as a source of enzyme for cathepsin D assays following the instructions of the manufacturer. Porcine gastric mucosa pepsin was purchased from Sigma (catalog \#P-6887) and used as a source of enzyme for pepsin assays following the instructions of the manufacturer. Recombinant renin from the SensoLyte Tm 520 renin assay kit (catalog \#72040; AnaSpec) was used as a source of enzyme for renin assays following the instructions of the manufacturer. For all enzyme assays, the 10-point inhibition curve was plotted and fitted with the four-parameter logistic equation to obtain the $\mathrm{IC}_{50}$ values.

\section{Cell-based assays}

The human embryonic kidney cell line HEK293 (ATCC accession number CRL-1573) stably expressing a human APP751 cDNA containing the naturally occurring double mutation N670L671 (APP770 amino acid numbering), commonly called the Swedish mutation and shown to overproduce $A \beta$ (Citron et al., 1992), was used routinely for the measurement of inhibition of BACE1 activity in whole cells (HEK293 $3_{\text {Swe }}$ assay). Media was analyzed for $A \beta$ peptides by specific ELISAs as described by Dovey et al. (2001). Compound cytotoxicity in the HEK293 $3_{\text {Swe }}$ cell model was assessed using a CellTiter 96 Aqueous Non-Radioactive Cell Proliferation Assay from Promega (catalog \#G5430) according to the recommendations of the manufacturer.

Primary neuronal cultures from embryonic PDAPP mice were used as a secondary whole-cell assay for BACE1 inhibition (PDAPP $1^{\circ}$ neuronal assay). PDAPP is a transgenic mouse animal model overexpressing a human APP mini-gene that harbors a familial mutation (APP V717F), which recapitulates much of the amyloid pathology observed in AD (Games et al., 1995). Primary cortical neurons from embryonic day 16 PDAPP embryos were incubated in the presence/absence of inhibitors at the desired concentration. Assays were conducted in triplicate. At the end of the incubation, conditioned media were analyzed for $A \beta$ peptides by specific ELISAs as described in the section below. Compound cytotoxicity in the PDAPP primary neuronal cultures was assessed using the MTT assay well described in the literature.

$\mathrm{A} \beta$ peptides were measured by sandwich ELISAs, using monoclonal $2 \mathrm{G} 3$ as a capture antibody for $\mathrm{A} \beta_{1-40}$, monoclonal $21 \mathrm{~F} 12$ as a capture antibody for $\mathrm{A} \beta_{1-42}$, and biotinylated 3D6 as reporting antibody (for description of $A \beta$ monoclonal antibodies, see JohnsonWood et al., 1997)). Culture media was diluted to allow determination of $\mathrm{A} \beta \mathrm{s}$ within the range of standards $(0-1000 \mathrm{pg} / \mathrm{ml})$. For both cell culture systems, the concentration of $\mathrm{A} \beta$ released in the conditioned media was considered reflective of BACE1 inhibition. The 10 -point inhibition curve was plotted and fitted with the fourparameter logistic equation to obtain the $\mathrm{EC}_{50}$ or relative $\mathrm{IC}_{50}$ values for the compound effect.

\section{PDAPP mouse in vivo pharmacology}

In vivo pharmacology studies were conducted in young PDAPP transgenic mice essentially as described by Dovey et al. (2001). Young (2-3 months old) female hemizygous APP ${ }^{\mathrm{V} 717 \mathrm{~F}}$ transgenic mice (PDAPP) from Taconic ( private line 6042T) were used for these studies. Typically, 32-40 mice were randomly assigned by parental lineage into groups of six to eight. Studies included vehicle-treatment groups administered in $7 \%$ Pharmasolve by oral gavage in a $10 \mathrm{ml} / \mathrm{kg}$ dose volume. LY2811376treated mice were orally gavaged with the compound and killed at the indicated times. The use of animals in these pharmacology studies conformed to the Institutional Animal Care and Use Guidelines for Eli Lilly \& Co.. For analysis of parenchymal A $\beta, \mathrm{C} 99$ and sAPP $\beta$ brain samples were homogenized in $5.5 \mathrm{M}$ guanidine- $\mathrm{HCl}$ buffer, and extracts were collected, diluted, and filtered before ELISA.

\section{A $\beta$ ELISA determination}

Parenchymal $\mathrm{A} \beta$ levels were determined from appropriately diluted guanidine homogenates by sandwich ELISA as described above. A $\beta$ levels were interpolated from standard curves using XL-Fit for Excel. C99 protein levels in brain homogenates were determined by an automated sand- 
wich ELISA using an anti-APP C-terminal antibody (catalog \#8717; Sigma) to capture the analyte and biotinylated anti-APP antibody (3D6) to detect the $\mathrm{N}$ terminus of C99. sAPP $\beta$ protein levels in brain homogenates and CSF were determined by a manual sandwich ELISA using an anti-APP antibody (8E5) to capture the analyte, an anti-neo epitope antibody (GN2114 rabbit polyclonal) to bind the $\mathrm{C}$ terminus of the sAPP $\beta$ revealed by BACE enzyme cleavage, and an anti-rabbit HRP conjugate for colorometric detection. Unknowns were assayed in triplicate, and the concentration of analyte in a sample was interpolated from a four-parameter fit of the reference curve (XL-Fit for Excel). Replicate samples with a coefficient of variation of $>15 \%$ or falling above or below the formal limits of quantitation were excluded from the analyses. ELISA values were normalized to protein levels (determined in duplicate by the Bradford Coomassie Plus Protein method) and expressed as picograms per milligrams $(\mathrm{A} \beta)$ or nanograms per milligrams (C99 and $\mathrm{sAPP} \beta)$ protein.

\section{Beagle dog in vivo pharmacology}

Beagle dogs were used as the secondary in vivo pharmacology model to assess BACE1 inhibition in a nontransgenic animal model with physiologic levels of APP expression. A plasma pharmacokinetics (PK)/PD study was conducted in beagle dogs. On day 0 of this study, three plasma samples were collected from four dogs (two male and two female) at $-1,-0.5$, and $0 \mathrm{~h}$ before receiving a vehicle (PBS) dose. The mean value of plasma concentrations of $\mathrm{A} \beta_{1-x}$ from these three samples were used as a baseline for each animal. The average predose baseline plasma $\mathrm{A} \beta_{1-x}$ for the four dogs was $340 \pm 14.2 \mathrm{pg} / \mathrm{ml}$ (mean \pm SEM, $n=4$ ). After dosing, plasma was collected at multiple time points out to $48 \mathrm{~h}$ and frozen for later analysis. Dogs were allowed 1 week to recover and then on day 7 were administered a 5 $\mathrm{mg} / \mathrm{kg}$ oral dose of LY2811376.2 HCl, and plasma samples were collected under the same schedule as the week before. After another week for recovery, on day 14, the dogs received another $5 \mathrm{mg} / \mathrm{kg}$ dose of LY2811376.2 HCl, and plasma samples were collected as before.

As a companion to the plasma PK/PD study described above, efficacy in a central compartment was evaluated in the same study animals by collecting cisternal CSF at selected time points after vehicle or $5 \mathrm{mg} / \mathrm{kg}$ doses of $\mathrm{LY} 2811376 \cdot 2 \mathrm{HCl}$ and measuring a variety of $\mathrm{A} \beta$ species. For these studies, dogs were anesthetized, and $1 \mathrm{ml}$ samples of CSF were collected by a cisternal tap. CSF samples that were grossly bloody were excluded from the analyses. For the day 0 vehicle-treatment group, CSF taps were collected at 3 and $24 \mathrm{~h}$ after dosing. These two values were averaged and used as the baseline for each dog. The average baseline CSF $\mathrm{A} \beta_{1-x}$ for the four dogs was $12,409 \pm 1014 \mathrm{pg} / \mathrm{ml}$ (mean \pm SEM, $n=4$ ). After a $7 \mathrm{~d}$ recovery period, the same dogs were administered a $5 \mathrm{mg} / \mathrm{kg}$ dose of LY2811376 $2 \mathrm{HCl}$, and cisternal CSF samples again were collected at 3 and $24 \mathrm{~h}$ after dose. Finally on day 14, the same dogs were administered another $5 \mathrm{mg} / \mathrm{kg}$ dose, and cisternal CSF samples were collected at $9 \mathrm{~h}$ as well as 24 and $48 \mathrm{~h}$ after dose. The use of animals in these pharmacology studies conformed to the Institutional Animal Care and Use Guidelines for Eli Lilly \& Co.

Cisternal CSF and plasma concentrations of $\mathrm{A} \beta_{1-x}$ (also known as $\mathrm{A} \beta$ total) were determined by standard sandwich ELISA protocols using $\mathrm{m} 266.2$ and biotinylated 3D6 (anti-A $\beta_{1-5}$ ) as the capture and reporter antibodies, respectively. Unknowns were assayed in duplicate, and picograms per milliliters was determined by interpolating (Soft Max Pro version 5.0.1; Molecular Dynamics) from eight-point standard curves and then adjusted for dilution. Replicate samples with a coefficient of variation of $>15 \%$ or falling above or below the formal limits of quantitation were excluded from the analyses. Grossly bloody cisternal CSF taps were excluded from the analysis.

\section{Statistical methods}

Statistical significance was determined by ANOVA using GraphPad Prism software. If significant, treatment groups were compared with controls using Dunnett's method. Significance was set as a $p$ value of $\leq 0.05$.

\section{Preclinical toxicology studies}

Sprague Dawley [Crl:CD(SD)] rats from Charles River Laboratories (10 per sex per group), $\sim 7$ weeks of age, were given 0 (vehicle only), 10, 30, or $100 \mathrm{mg} / \mathrm{kg}$ LY2811376 by daily oral gavage. Vehicle consisted of $1 \%(\mathrm{w} / \mathrm{v})$ hydroxyethylcellulose, $0.25 \%(\mathrm{v} / \mathrm{v})$ polysorbate 80 , and $0.05 \%(\mathrm{v} / \mathrm{v})$ Dow Corning Antifoam 1510-US in reverse osmosis water. At necropsy after 3 months of treatment, tissues were immersion fixed in $10 \%$ neutralbuffered formalin (brain) or modified Davidson's solution (eyes) and then processed by routine methods to paraffin block and hematoxylineosin (H\&E)-stained histologic slides. From selected animals given 100 $\mathrm{mg} / \mathrm{kg}$ on a subsequent investigative study, eyes were fixed in modified Karnovsky's solution, processed routinely into epoxy resin, and then ultrathin sections stained with uranyl acetate and Sato's lead citrate were examined in a transmission electron microscope. The use of animals in these toxicology studies conformed to the Institutional Animal Care and Use Guidelines for the contract laboratory and sponsor. In a separate study, BACE1 knock-out mice (B6.129-Bace $\left.1^{\mathrm{tm} 1 \mathrm{Pcw}} / \mathrm{J}\right)$ were given 0 or $100 \mathrm{mg} / \mathrm{kg}$ LY2811376 by daily oral gavage for 9 weeks, and then necropsied tissues were collected and examined by light microscopy as described above for the rat toxicology study.

\section{Methods for the clinical study}

Study design. The CSF sampling portion of the study was a subject- and investigator-blind, placebo-controlled, randomized, single-dose design in healthy subjects. The study assessed the safety and tolerability as well as plasma and CSF PK/PD. The study was conducted at PAREXEL International Early Phase Los Angeles, from February to June 2009. The California Institutional Review Board approved the study. All subjects provided written informed consent before the beginning of the study. The trial was conducted in compliance with the Declaration of Helsinki and International Conference on Harmonisation/Good Clinical Practice guidelines.

Subjects. Thirty healthy subjects (21-49 years old, 27 males) participated in the CSF sampling portion of the study.

Procedures. Subjects were randomly assigned to receive a single dose of $30 \mathrm{mg}$ of LY2811376, $90 \mathrm{mg}$ of LY2811376, or placebo in the fasted state. Safety was assessed before and after dosing by recording adverse events, physical and neurological examinations, vital signs, electrocardiograms, and results of clinical safety laboratory tests. The indwelling lumbar catheter was placed by anesthesiologists $\sim 4$ h before administration of study drug, and subjects remained supine for the duration of the CSF sample collection period. Up to 22 CSF samples were collected at regular intervals, from $4 \mathrm{~h}$ before study drug administration up to $36 \mathrm{~h}$ after study drug administration (approximately $-4,-2,0,1,2,3,4,5,6,7,8,9,10,12,14,16,18,20,24,28,32$, and $36 \mathrm{~h}$ after dose). All CSF samples were collected in polypropylene tubes and stored at $-20^{\circ} \mathrm{C}$ or below. In addition, up to 13 plasma samples (before dose and $\sim 0.5,1,2,4,6,8,12,24,36,48,60$, and $96 \mathrm{~h}$ after dose) were collected on each subject; the plasma time points were selected based on the preclinical plasma $A \beta$ data.

Bioanalytical methods. Plasma $\mathrm{A} \beta_{1-40}$ and $\mathrm{A} \beta_{1-x}$ and CSF $\mathrm{A} \beta_{1-40}$, $\mathrm{A} \beta_{1-42}$, sAPP $\alpha$, and sAPP $\beta$ were measured by PPD Inc. using validated ELISAs. $\mathrm{A} \beta_{1-40}, \mathrm{~A} \beta_{1-42}$, and $\mathrm{A} \beta_{1-x}$ captured using monoclonal $2 \mathrm{G} 3,21 \mathrm{~F} 12$, and 266.2 , respectively, were colorimetrically quantified using biotinylated monoclonal 3D6, a streptavidin-HRP conjugate, and TMB substrate. Plasma $\mathrm{A} \beta_{1-40}$ and $\mathrm{A} \beta_{1-x}$ assays were validated over concentration ranges of $25-800$ and $28-600 \mathrm{pg} / \mathrm{ml}$, respectively. The CSF $\mathrm{A} \beta_{1-40}$ and $\mathrm{A} \beta_{1-42}$ assays were validated over a concentration range of $25-400 \mathrm{pg} / \mathrm{ml}$ for both analytes. CSF sAPP $\alpha$ and sAPP $\beta$ were measured using a commercially available assay kit (Meso Scale Discovery) validated over a concentration range of 200-100,000 $\mathrm{pg} / \mathrm{ml}$ for both analytes.

Plasma and CSF samples were analyzed for LY2811376 using validated liquid chromatography with tandem mass spectrometric detection methods by Covance Laboratories. Deuterated LY2811376 was added to each sample as an internal standard. Separation was achieved using a gradient HPLC system with a Prodigy ODS(3) column $(5 \mu \mathrm{m}, 50 \times 2.0$ $\mathrm{mm}$; Phenomenex) using mobile phase A $(0.2 \%$ formic acid in water $)$ and mobile phase B ( $0.2 \%$ formic acid in acetonitrile). After separation, 


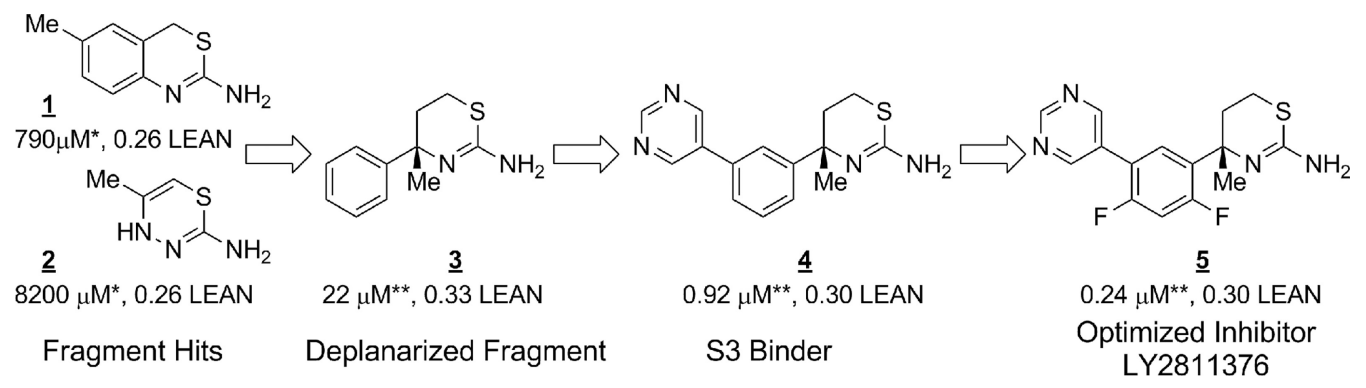

Figure 1. Optimization of BACE1 inhibitor from initial fragment hits entailed deplanarization of bicyclic fragment to enhance occupancy of $\mathrm{S1}$ pocket, introduction of an $\mathrm{S3}$ binding element to increase affinity, and optimization of final inhibitor for in vivo performance. * hBACE1 MBP-C125 ELISA assay; ${ }^{* *}$ hBACE1 mcaFRET assay.

LY2811376 was detected using a Sciex API 4000 in positive ion mode monitoring the transition mass/charge $321 \rightarrow 217$. The validated concentration range for plasma was $1-5000 \mathrm{ng} / \mathrm{ml}$ and for CSF was $0.5-500$ $\mathrm{ng} / \mathrm{ml}$. CSF red blood cell counts were also measured on two predose samples at the local laboratory (Glendale Adventist Medical Center Laboratory).

Clinical statistical analyses. Statistical analysis of percentage change from baseline of CSF A $\beta_{1-40}$ concentrations obtained over the fixedschedule sampling period were analyzed using a repeated-measures analysis with the primary statistical inference of pairwise comparison of the overall mean difference of low-dose LY2811376 (30 mg) with placebo and high-dose LY2811376 (90 mg) with placebo using an $80 \%$ confidence interval (this is equivalent to a one-sided hypothesis test with $\alpha=0.1$ ). The statistical model included the baseline CSF A $\beta_{1-40}$ concentrations obtained during predose CSF collection periods and fixed effects of dose groups (placebo, low-dose LY2811376, and highdose LY2811376), scheduled CSF sampling time, and the interaction between dose groups and sampling times. A compound symmetric covariance structure was used. Additional exploratory analyses included the analysis of percentage change from baseline of CSF A $\beta_{1-42}$, $\operatorname{sAPP} \alpha$, and $\operatorname{sAPP} \beta$. The statistical model included fixed effects of dose, sampling time, and the statistical interaction term with a compound symmetric covariance structure.

\section{Results}

Fragment-based discovery and optimization of LY2811376

Informed by the community experience with peptidomimetic and HTS-derived inhibitors of BACE1, we chose to explore a fragment-based screening approach (Erlanson et al., 2004), keenly focused on identifying a ligand-efficient starting point suitable for producing a lead compound capable of facile target access within the CNS. Ligand efficiency can be variably defined (Hopkins et al., 2004) but in this context is a measurement of the contribution of each individual atom to the overall binding energy of a ligand to its protein target.

Screening a collection of $\sim 8000$ fragments at high concentration $(4.76 \mathrm{mM})$ against BACE1 with a maltose binding protein-fusion protein substrate (Sinha et al., 1999) produced a number of low-affinity fragment hits with high LEAN values [LEAN is an internal metric for ligand efficiency and is defined as $-\log \left(\mathrm{IC}_{50}\right) /$ number of non-hydrogen atoms]. Of particular interest were amino-benzothiazine (Fig. 1, 1) and aminothiadiazine (Fig. 1, 2) (Sharma et al., 1963), which met our initial criteria for ligand efficiency and possessed attractive physicochemical properties for subsequent optimization. An important advance for our effort was the successful crystal soaking experiment of $\boldsymbol{1}$ in Figure 1 with a soluble construct for BACE1, revealing two copies of the inhibitor with high active-site occupancy and an open-flap protein conformation. One copy engaged in an efficient $\mathrm{H}$-bonding interaction with the catalytic diad of BACE1, whereas a second copy extended across the S1-S3 cavity. Recognizing that the rigid bicyclic scaffold of the aspartate-binding benzothiazine failed to afford optimal vectors for fragment growth into S1-S3, we excised the fused aryl ring, effectively deplanarizing the aminothiazine, and introduced a quaternary methyl group to both exacerbate this topology and enhance chemical stability, yielding 3 in Figure 1. BACE1 recognized only a single enantiomer of this now chiral inhibitor, achieving a substantial increase in potency while maintaining excellent efficiency of the ligandprotein interactions. Surprisingly, however, inhibitor 3 in Figure 1 also revealed two copies bound to the BACE1 active site during crystal-soaking experiments, again with one copy productively engaged with the catalytic aspartates and the second in an S1-S3 role. Extension of the inhibitor with a suitable S3 motif such as a pyrimidine now produced an inhibitor competent to play both roles. A series of tricyclic aminothiazines similar to 4 in Figure 1 soaked into BACE1 crystals with a single bound copy, now achieving micromolar potency with only 20 heavy atoms. Deactivation of the metabolically labile central aryl ring with fluorines reduced in vivo clearance and also provided a welcome enhancement in potency, breaking the micromolar barrier with high ligand efficiency. As evidenced by x-ray co-crystal structure (Fig. 2), LY2811376 (Fig. 1, 5) retained an optimal $\mathrm{H}$-bonding network with the catalytic aspartates, efficiently traversed $\mathrm{S} 1$ and projected the pyrimidine into the opening of S3.

\section{In vitro characterization of LY2811376}

In recombinant enzyme assays, LY2811376 demonstrated concentration-dependent inhibition of hBACE1 with an $\mathrm{IC}_{50}$ of 239 and $249 \mathrm{~nm}$ against a small synthetic peptide or a larger chimeric protein substrate, respectively (Table 2). Because of limitations of substrate solubility (MBP-C125 assay) or inner-filter effects (mcaFRET assay), bona fide $K_{\mathrm{m}}$ values for each substrate were not determined. However, rather than being used for detailed kinetic analyses, these enzyme assays were optimized to be highly reproducible and detect differences in potency from compound to compound to drive the structure-activity relationship. LY2811376 demonstrated $\sim 10$-fold selectivity toward BACE1 over BACE2, a related aspartyl protease, and 50-fold or greater separation between inhibition of BACE1 and the more distantly related aspartyl proteases cathepsin $\mathrm{D}$, pepsin, or renin (Table 2). In an APP-overexpressing human embryonic kidney cell line, LY2811376 treatment yielded a concentration-dependent decrease in $\mathrm{A} \beta$ secretion with a half-maximal effective concentration $\left(\mathrm{EC}_{50}\right.$ ) of $\sim 300 \mathrm{~nm}$ (Table 3). LY2811376 treatment of primary neuronal cultures of PDAPP transgenic mouse produced a concentration-dependent decrease in $\mathrm{A} \beta$ secretion with an $\mathrm{EC}_{50}$ of $\sim 100 \mathrm{~nm}$ (Table 3). These reductions in $\mathrm{A} \beta$ were 


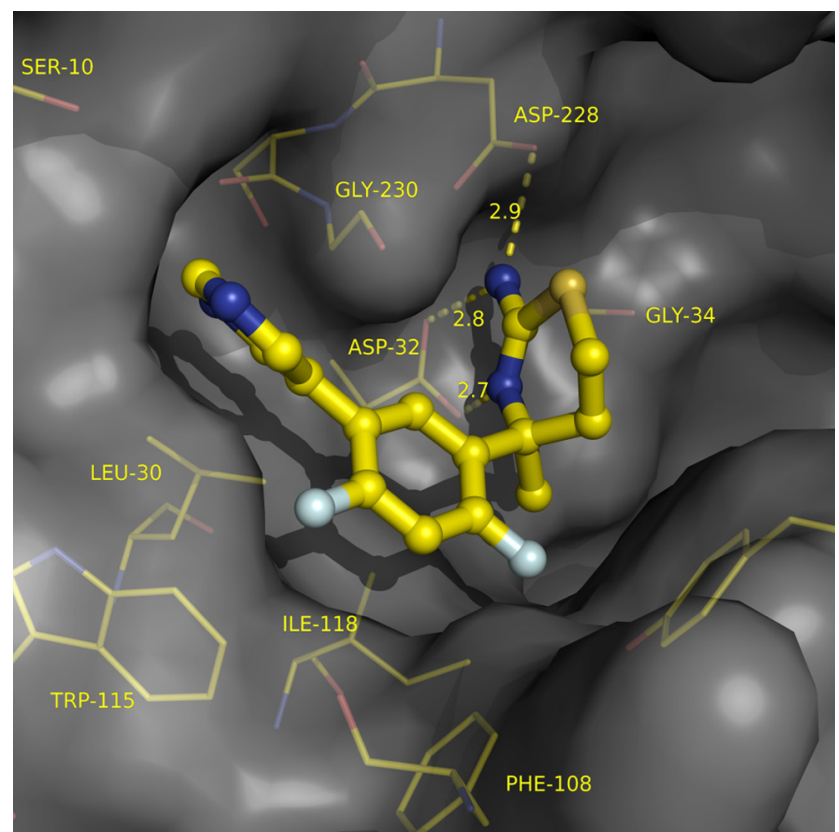

Figure 2. Co-crystal structure of LY2811376 in BACE1 active site (flap not shown for clarity). Structure factors and protein coordinates to be deposited into Protein Data Bank.

achieved in the absence of any detectable cytotoxic effects on cells, as shown in Table 3. Thus, although LY2811376 may not display the exquisite intrinsic potency of other reported BACE1 inhibitors, it is highly cell penetrant and as a result efficiently inhibits native murine and human BACE1 in a cellular environment.

\section{In vivo characterization of LY2811376 in preclinical animal models}

To assess BACE1 inhibition in vivo, we used the APP ${ }^{\mathrm{V717F}}$ mouse, a transgenic animal model of A $\beta$ pathology (Games et al., 1995). Young mice were administered LY2811376 by oral gavage and killed at $3 \mathrm{~h}$ after dosing to assess brain levels of relevant PD markers of BACE target engagement. Systemic exposures averaged 667,1830 , and $7200 \mathrm{ng} / \mathrm{ml}$ at the 10,30 , and $100 \mathrm{mg} / \mathrm{kg}$ doses, respectively. The optimized physiochemical properties of the molecule, e.g., molecular weight of $320, \log \mathrm{P}$ of 2.38 , and polar surface area of 64 , resulted in a molecule that was highly brain penetrant with brain exposures of 1460, 3352, and 12,120 $\mathrm{ng} / \mathrm{g}$ achieved for the 10,30 , and $100 \mathrm{mg} / \mathrm{kg}$ doses, respectively. Consistent with brain exposures exceeding the cellular $\mathrm{IC}_{50}$, administration of LY2811376 resulted in dose-dependent, significant reductions in $\mathrm{A} \beta$ (Fig. 3A), as well as sAPP $\beta$ and $\mathrm{C} 99$, the proximal cleavage products of APP proteolysis by BACE1 (Fig. $3 B, C)$. The concordant inhibition of all three relevant biomarkers supports an in vivo mechanism of action for LY2811376 consistent with BACE1 inhibition in brain after acute administration of LY2811376. However, LY2811376 is rapidly cleared in mice, resulting in overall low sustained exposure profiles at orally administered pharmacological doses, which dissuaded us from pursuing chronic administration studies in transgenic mice to investigate effects on $\mathrm{A} \beta$ amyloid plaque lowering.

Beagle dogs permitted confirmation of the in vivo pharmacology in a nontransgenic animal model. Effects on both plasma and CSF A $\beta$ were assessed after oral gavage of a $5 \mathrm{mg} / \mathrm{kg}$ dose of LY2811376. LY2811376 was rapidly absorbed with $C_{\max }$ values of $1915 \mathrm{ng} / \mathrm{ml}$ after $\sim 1 \mathrm{~h}$ after dosing $\left(T_{\max }=0.81 \mathrm{~h}\right)$. Overall plasma exposure averaged $12,300 \mathrm{ng} \cdot \mathrm{ml}^{-1} \cdot \mathrm{h}^{-1}$ area under the concentration time curve (AUC), with a $T_{1 / 2}$ of $6.8 \mathrm{~h}$. After treatment with LY2811376, reductions in $\mathrm{A} \beta_{1-x}$ were observed in plasma, with a maximal $85 \%$ reduction observed from 4 to $12 \mathrm{~h}$ after dosing (Fig. 3D). Plasma A $\beta_{1-x}$ levels remained below baseline $24 \mathrm{~h}$ after dosing. These significant changes in plasma $\mathrm{A} \beta$ were mirrored in the CSF compartment. Relative to baseline, CSF $\mathrm{A} \beta_{1-x}$ levels were reduced $43 \%$ by $3 \mathrm{~h}$ after oral administration of $5 \mathrm{mg} / \mathrm{kg}$ LY2811376 (Fig. 3D). By $9 \mathrm{~h}$, the effect size increased to $\sim 70 \%$ reduction in CSF $\mathrm{A} \beta_{1-x}$. Comparable reductions in CSF $\mathrm{A} \beta_{1-40}$ and $\mathrm{A} \beta_{1-42}$ as well as the potentially $\mathrm{N}$-terminal truncated species $\mathrm{A} \beta_{x-40}$ and $\mathrm{A} \beta_{x-42}$ were observed at these same time points after LY2811376 treatment (results not shown). The concordant inhibition of various $A \beta$ isoforms in CSF supports an in vivo mechanism of action for LY2811376 consistent with BACE1 inhibition in brain.

\section{PK/PD characterization of LY2811376 in healthy volunteers}

A single ascending dose (SAD) study and a follow-up CSF sampling study were conducted in healthy human subjects to characterize peripheral and central LY2811376 PK/PD. Plasma LY2811376, $\mathrm{A} \beta_{1-40}$, and $\mathrm{A} \beta_{1-x}$ concentrations were measured in the SAD study over $96 \mathrm{~h}$ with oral administration of placebo or LY2811376 at doses ranging from 5 to $90 \mathrm{mg}$. Low $(30 \mathrm{mg})$ and high (90 mg) doses of LY2811376 investigated in the CSF sampling study were based on $\mathrm{PK}$ and plasma $\mathrm{A} \beta_{1-40} \mathrm{PD}$ observed in the SAD study (Fig. 4). Individuals participating in the CSF sampling study were randomly assigned to oral administration of placebo, $30 \mathrm{mg}$ of LY2811376, or $90 \mathrm{mg}$ of LY2811376 ( $n=10$ in each group). Concentrations of LY2811376, $\mathrm{A} \beta_{1-40}, \mathrm{~A} \beta_{1-42}$, $\operatorname{sAPP} \alpha$, and $\operatorname{sAPP} \beta$ were measured in CSF collected for $36 \mathrm{~h}$ via an indwelling lumbar sac catheter. Plasma concentrations of LY2811376, $\mathrm{A} \beta_{1-40}$, and $\mathrm{A} \beta_{1-x}$ also were measured in the CSF sampling study.

Maximum plasma concentrations of LY2811376 were reached $2 \mathrm{~h}$ after dosing, and the mean terminal half-life was $\sim 40 \mathrm{~h}$. At 90 $\mathrm{mg}$, the mean observed maximum concentration and AUC (time, $0-\infty$ ) were $242 \mathrm{ng} / \mathrm{ml}$ and $4560 \mathrm{ng} \cdot \mathrm{ml}^{-1} \cdot \mathrm{h}^{-1}$, respectively. Maximum concentrations of LY2811376 in CSF were reached at $\sim 5 \mathrm{~h}$, which is delayed relative to plasma concentrations. This delay is consistent with expectations (Bateman et al., 2009) based on the CSF samples being collected from lumbar region rather than the cisterna magna. The relationship between plasma and CSF LY2811376 AUC appeared to be linear, with the AUC in CSF approximately threefold lower than in plasma.

Single doses of LY2811376 resulted in significant and dosedependent reductions in plasma $\mathrm{A} \beta_{1-40}$ (Fig. $5 A$ ), with a mean reduction over the first $24 \mathrm{~h}$ of $64 \%$ and reductions at the observed nadir ( $\sim 7 \mathrm{~h}$ after dosing) of $80 \%$ after the $90 \mathrm{mg}$ dose. After the $90 \mathrm{mg}$ dose, plasma concentrations of $\mathrm{A} \beta_{1-40}$ did not fully return to their predose baseline values within the $120 \mathrm{~h}$ sampling period of the dose-escalation part of the study. The reduction of plasma $A \beta_{1-x}$ was similar to plasma $A \beta_{1-40}$.

Single doses of LY2811376 also resulted in significant and dose-dependent reductions in CSF $A \beta_{1-40}$ and $A \beta_{1-42}$ (Fig. $5 B, C)$. A repeated-measures mixed-model analysis was used to compare differences among the treatment groups during the $36 \mathrm{~h}$ sampling period. The maximum mean reduction from baseline concentration for the 30 and $90 \mathrm{mg}$ doses was $\sim 20 \pm 17$ and $54 \pm$ $17 \%$, respectively. The 30 and $90 \mathrm{mg}$ doses showed a significant mean reduction compared with placebo by $7 \mathrm{~h}$ after dose and reached a maximum reduction at $12-14 \mathrm{~h}$ after dose. The average reduction in CSF $\mathrm{A} \beta_{1-40}$ over the first $24 \mathrm{~h}$ was $33 \%$, and the reduction at the observed nadir ( $\sim 18 \mathrm{~h}$ after dosing) was $54 \%$ 
Table 2. Potency of LY2811376 in BACE1 and related aspartyl protease assays

\begin{tabular}{|c|c|c|c|c|c|c|}
\hline Assay & hBACE1 MBP-C125 $5_{\text {Swe }}$ & hBACE1 mcaFRET & hBACE2 mcaFRET & Cathepsin D FRET & Pepsin FRET & Renin FRET \\
\hline $\mathrm{IC}_{50} \pm \mathrm{SD}(\mathrm{nM})$ & $249 \pm 309(4)$ & $239 \pm 73(8)$ & $2880 \pm 19(2)$ & $15700 \pm 1830(2)$ & $32567 \pm 13947(2)$ & $39027 \pm 1720(2)$ \\
\hline
\end{tabular}

Data are given as mean \pm SD of two to eight independent assays conducted as described in Materials and Methods. $n$ values are in parentheses.

Table 3. Potency of LY2811376 cellular APP processing assays

\begin{tabular}{|c|c|c|c|c|c|c|}
\hline Assay & HEK293 ${ }_{\text {Swe }} A \beta_{1-40}$ & HEK293 ${ }_{\text {Swe }} A \beta_{1-42}$ & HEK293 ${ }_{\text {Swe }}$ Cytotoxicity & PDAPP $1{ }^{\circ}$ neuronal $A \beta_{1-40}$ & PDAPP $1{ }^{\circ}$ neuronal $A \beta_{1-42}$ & PDAPP $1^{\circ}$ neuronal cytotoxicity \\
\hline $\mathrm{IC}_{50} \pm \mathrm{SD}(\mathrm{nm})$ & $303 \pm 112(5)$ & $299 \pm 58(4)$ & $>100,000(5)$ & $115 \pm 42(4)$ & $106 \pm 46(5)$ & $>50,000(4)$ \\
\hline
\end{tabular}

Data are given as mean \pm SD of four to five independent assays conducted as described in Materials and Methods. $n$ values are in parentheses.

after the $90 \mathrm{mg}$ dose. In the placebotreated subjects, concentrations of CSF $\mathrm{A} \beta_{1-40}$ and $\mathrm{A} \beta_{1-42}$ increased over time without a return to baseline after $24 \mathrm{~h}$. This phenomenon appears to be related to the CSF collection procedure and has been reported by other researchers (Bateman et al., 2007). Accounting for the increase in the placebo group, the average reduction over the first $24 \mathrm{~h}$ in the CSF concentration of $\mathrm{A} \beta_{1-40}$ for the $90 \mathrm{mg}$ dose relative to placebo was $\sim 56 \%$. The magnitude of the reduction in CSF A $\beta_{1-42}$ was very similar to that in $\operatorname{CSF} \mathrm{A} \beta_{1-40}$.

Single doses of LY2811376 resulted in significant and dose-dependent reductions in CSF sAPP $\beta$ (Fig. $5 E$ ), providing direct evidence of $\beta$-secretase inhibition in the human CNS. The $90 \mathrm{mg}$ LY2811376 dose showed a maximum reduction of sAPP $\beta$ concentration of $42 \%$, which occurred after $20 \mathrm{~h}$. LY2811376 also resulted in increased concentrations of $\operatorname{sAPP} \alpha$ (Fig. 5D) with 76\% maximum increase for the $90 \mathrm{mg}$ dose of LY2811376, which suggests that inhibition of $\beta$-secretase in humans resulted in a compensatory increase in APP cleavage at the $\alpha$ site. Concentrations of $\operatorname{sAPP} \alpha$ appeared to continue to increase during the $36 \mathrm{~h}$ sampling period.

Overall, LY2811376 was well tolerated in the CSF study. There were no serious adverse events, and all 27 treatmentemergent adverse events were mild or moderate in severity. The most frequent treatment-emergent adverse events were procedural headache $(n=15)$ and catheter site pain $(n=7)$. There were no clinically significant alterations in vital signs, laboratory analytes, or electrocardiograms associated with LY2811376 treatment during the dosing period.

\section{Preclinical toxicologic findings of retinal pathology}

In parallel to the phase 1 studies in healthy volunteers, a 3 month rat toxicology study was performed to prepare for longer exposures in phase 2 clinical trials. LY2811376 caused cytoplasmic accumulations of finely granular autofluorescent material dispersed within the retinal epithelium (Fig. 6) and less prominently within neurons and glial cells in the brain at doses $\geq 30 \mathrm{mg} / \mathrm{kg}$. The autofluorescence was observed when $\mathrm{H} \& \mathrm{E}$-stained slides were observed with epifluorescent illumination (Leica cube I3: excitation, 450-490 nm bandpass; emission barrier filter, $515 \mathrm{~nm}$ long pass). The retinal epithe-
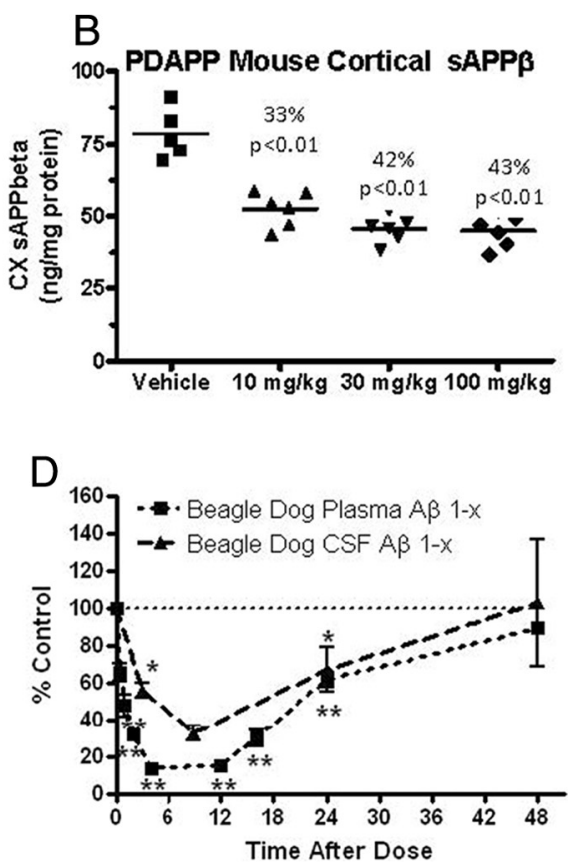

Figure 3. Pharmacologic effects in vivo of oral administration of $L Y 2811376$. $\boldsymbol{A}-\boldsymbol{C}$, PDAPP mice ( $n=6$ per group) were treated with increasing doses of LY2811376 or vehicle, and $A \beta(\boldsymbol{A}), \operatorname{SAPP} \beta(\boldsymbol{B})$, or $C 99(\boldsymbol{C})$ levels were determined from cortical extracts obtained $3 \mathrm{~h}$ after dosing. LY2811376 produced dose-dependent decreases in all APP-related PD markers

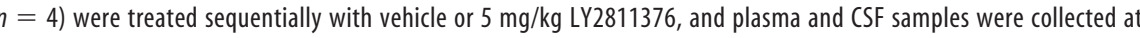
arious times after dosing. The average predose baseline plasma $A \beta_{1-x}$ was $340 \pm 14.2 \mathrm{pg} / \mathrm{ml}$ (mean $\left.\pm \mathrm{SEM}, n=4\right)$. The me-dependent decreases in $A \beta_{1-x}$ in both plasma and CSF of dog compared with baseline control values. ${ }^{*} p<0.05$, ${ }^{* *} p<0.01$ versus baseline controls, ANOVA/Dunnett's post hoc analysis.

lial cells were enlarged because of the burden of accumulated material, there was photoreceptor degeneration within the sensitive retina, and neuronal degeneration was present in brain. In a subsequent repeat-dosing investigative study, the retinal epithelial change was characterized ultrastructurally by notably increased numbers of secondary lysosomes containing partially degraded photoreceptor outer segment material, which caused the cellular enlargement.

A subsequent study using LY2811376 in BACE1 $1^{-/-}$mice demonstrated that the findings observed in the retinal epithelium and brain were unrelated to the BACE1 pharmacological target. Treatment of $B A C E 1^{-/-}$mice from The Jackson Laboratory (strain BACE1tm1Pcw; Johns Hopkins University, Baltimore, MD) with $100 \mathrm{mg} / \mathrm{kg}$ LY2811376 for 9 weeks resulted in accumulated autofluorescent material and degenerative changes in the retinal epithelium comparable with the changes observed in rats given similar doses, whereas the eyes of vehicle-treated $B A C E 1^{-/-}$mice were histologically unremark- 

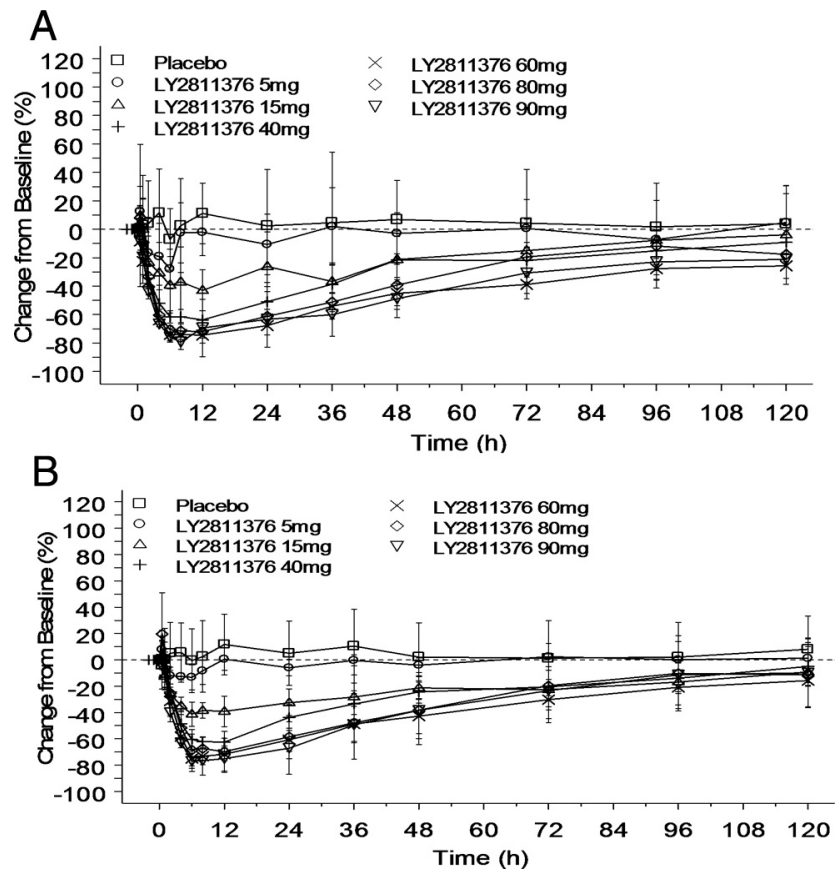

Figure 4. SAD study in healthy volunteers. Mean plasma $A \beta_{1-40}(\boldsymbol{A})$ and $A \beta_{1-x}(\boldsymbol{B})$ change from baseline after single doses of $L Y 2811376$. After single doses of $L Y 2811376$ between 5 and $90 \mathrm{mg}$, plasma concentrations of both $A \beta_{1-40}$ and $A \beta_{1-x}$ decreased, reached a nadir, and then slowly returned to their predose baseline values. The time at which the nadir occurred ranged from a mean of $6-12 \mathrm{~h}$ and appeared to be independent of dose. The magnitude of the decrease in plasma $A \beta_{1-40}$ and $A \beta_{1-x^{\prime}}$ as measured by either the nadir or the average reduction over the first $24 \mathrm{~h}$ tended to increase with increasing doses of LY2811376. Plasma concentrations of $A \beta_{1-40}$ and $A \beta_{1-x}$ after the highest dose of $90 \mathrm{mg}$ did not fully return to their predose baseline values within the $120 \mathrm{~h}$ sampling period of the study. Plasma $A \beta_{1-40}$ and $A \beta_{1-x} P D$ response provided guidance for dose selection to the second part of the trial looking at PD effect in CSF.

able. Intracellular autofluorescent granular material was present in the brains of treated $B A C E 1^{-1-}$ mice, although at considerably lower levels than occurred in treated rats; the material was not present in the untreated mice.

Importantly, as soon as these preclinical pathology data became available, clinical dosing of LY2811376 was discontinued, the Food and Drug Administration was notified, and the studies were terminated in agreement with the Food and Drug Administration. As a safety follow-up, all study participants were contacted for follow-up eye examinations. The examinations were conducted $\sim 6-10$ months after completion of the trial. They revealed no clinically significant observations in the 45 of the 61 enrolled subjects, who agreed to participate.

\section{Discussion}

Here, we report on the first small-molecule BACE1 inhibitor demonstrating robust translation from preclinical animal models to early-stage clinical testing in humans. A fragment-based, LEAN-driven drug discovery effort was used to circumvent many of the poor physiochemical properties that plagued the early BACE1 inhibitors. LY2811376 efficiently inhibits BACE1 activity in vivo as demonstrated by the coordinate reduction of the two primary APP cleavage products generated by BACE1, e.g., C99 and $\operatorname{sAPP} \beta$, coupled with a reduction of various $A \beta$ peptides beginning with the canonical BACE1 cleavage site as well as $\mathrm{N}$-terminal truncated $\mathrm{A} \beta$ species. Thus, small oral doses of LY2811376 effectively attenuate the amyloidogenic processing pathway of APP.
The significant reduction in brain and CSF A $\beta$ levels observed in preclinical animal models after oral administration of 5-10 $\mathrm{mg} / \mathrm{kg}$ doses of LY2811376 contrasts sharply with in vivo pharmacology studies reported for earlier BACE1 inhibitors. Although extremely potent BACE1 inhibitors have been optimized in vitro, their in vivo performance has suffered as a result of P-glycoprotein efflux issues, poor oral bioavailability and/or rapid clearance. To obtain comparable central effect sizes observed with LY2811376, other BACE1 inhibitors have had to be dosed in MDR1a KO mice (Meredith et al., 2008) or in conjunction with a P-glycoprotein inhibitor (Hussain et al., 2007) to permit sufficient brain exposure to be achieved. Similarly, coadministration of a Cyp3A4 inhibitor to block first-pass metabolism was required to permit sufficient systemic exposure after oral gavage of a BACE1 inhibitor to achieve central BACE1 inhibition in a nonhuman primate model (Sankaranarayanan et al., 2009).

Although some progress with BACE1 inhibitors in preclinical models has been reported at recent meetings, comparable clinical $\mathrm{PD}$ responses in plasma and CSF in humans have not been reported previously. The group at CoMentis has reported in a preliminary communication robust changes in plasma $\mathrm{A} \beta$ after intravenous infusion of CTS 21166, a potent BACE1 inhibitor to healthy volunteers (Strobel, 2008), but no central pharmacology has been reported to date. Thus, to our knowledge, our data with LY2811376 represent the first demonstration of robust and sustained reduction of lumbar CSF A $\beta$ in healthy volunteers dosed with a BACE1 inhibitor. Importantly, the reduction in $\mathrm{A} \beta$ levels is accompanied by sustained reduction of lumbar CSF sAPP $\beta$, the primary cleavage product of BACE1 cleavage of APP.

Our study of LY2811376 revealed retinal pathology in longerterm nonclinical toxicology studies. Although the mechanism driving this pathology is not clearly understood, it appears to be off-target because a similar adverse effect was obtained with longterm dosing of BACE1 KO mice with LY2811376. It cannot presently be ruled out that, at toxicologic doses, activity against other aspartyl proteases, such as BACE2 or even cathepsin D, might play a role in the retinal pathology observed with LY2811376. More research in this area is necessary. Importantly, however, safety follow-up exams in the clinical trial participants revealed no clinically significant observations from administration of LY2811376.

In addition to the retinal pathology observed in preclinical toxicology studies, there are theoretical concerns with BACE1 inhibition that have not been specifically addressed with LY2811376. These concerns stem from theoretical risks inferred from the study of BACE1 KO animals as well as an expanding complement of additional substrates posited for BACE1. Perhaps the best characterized substrate for BACE1 in addition to APP is Neuregulin-1 (Hu et al., 2006; Willem et al., 2006). Although initially characterized as having a minimal phenotype (Cai et al., 2001; Luo et al., 2001; Roberds et al., 2001), more careful study of BACE1 KOs revealed hypomyelination of the peripheral nervous system in neonates (Hu et al., 2006; Willem et al., 2006). Given the role that Type 3 Neuregulin-1 is known to play in myelination (Michailov et al., 2004), inappropriate processing of Neuregulin-1 would be consistent with the hypomyelination observed in neonates harboring a BACE1 deficiency. The hypomyelination phenotype was not noted in BACE1 hemizygous mice (Hu et al., 2006), and the phenotype noted in homozygous KOs appeared to diminish with age, suggesting that BACE1 KO delayed but did not block myelination. Consistent with this interpretation, genetic deficiency of BACE1 also delayed remyelination of the 
sciatic nerves in mice following an experimental neuronal crush model (Hu et al., 2008).

The voltage-gated sodium channel (VGSC; $\mathrm{Na}_{\mathrm{v}} 1$ ) $\beta$-subunits are another recently described substrate for BACE1 (Wong et al., 2005; Kim et al., 2007). These $\beta$-subunits are auxiliary proteins to the pore-forming $\alpha$ subunits and play a role in trafficking and regulation of VGSC (Brackenbury and Isom, 2008). Enhanced excitability and frank behavioral seizures have been noted in BACE1 KOs, a behavioral phenotype that may result from hyperexcitability of hippocampal circuitry attributable to altered VGSCs (Evin et al., 2003). However, a similar behavioral phenotype was also noted by Hitt et al. (2010) in a subset of BACE1 KO mice without altered VGSCs expression, so other mechanisms may be at play, and clearly additional investigation is needed.

There is currently no evidence that pharmacologic inhibition of BACE1 in adults would result in a similar phenotype as that observed with genetic knock-out. As noted above, the hypomyelination phenotype was not noted in BACE1 hemizygous mice expressing $50 \%$ of BACE1 in brain. In addition, pharmacologic inhibition achieved by direct central administration of a BACE1 inhibitor did not appear to alter Neuregulin-1 cleavage patterns in adult mouse brain (Sankaranarayanan et al., 2008), but functional deficits were not evaluated. Similarly, the deficits in behavioral cognitive tests, e.g., Morris water maze, Y maze, etc., observed in BACE knock-outs were not present in BACE1 hemizygous mice (Laird et al., 2005), suggesting that partial reduction in BACE1 activity may be better tolerated even when it already occurs during development. Finally, as a cautionary note about over-interpreting theoretical safety concerns from KO data, it should be noted that genetic $\mathrm{KO}$ of 3-hydroxy-3methylglutaryl-coenzyme A (HMG-CoA) reductase results in embryonic lethality (Ohashi et al., 2003), but statins that target HMG-CoA reductase remain one of the most widely prescribed classes of drugs in the world (Simmons, 2003).

In conclusion, this first description of an orally available CNS-active $\beta$-secretase inhibitor after more than a decade of research clearly demonstrates that BACE1 is a tractable target and that profound central $\mathrm{A} \beta$ lowering can be achieved by BACE1 inhibition in humans. The magnitude and duration of central $\mathrm{A} \beta$ reduction obtainable with $\mathrm{BACE} 1$ inhibition needs to be balanced against the possible on-target effects against other known substrates of BACE, unknown substrates yet to be discovered, as well
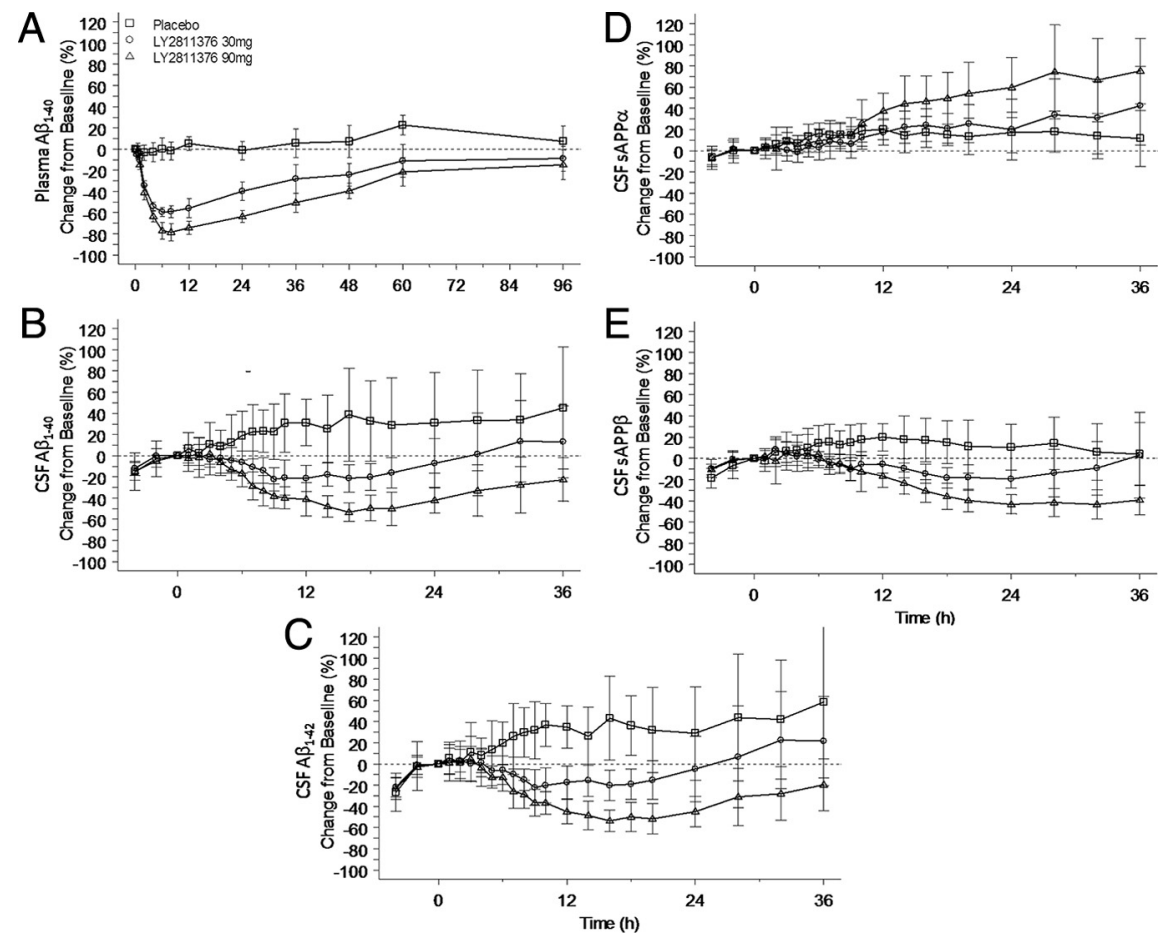

Figure 5. SADCSF sampling study in healthy volunteers. Single doses of 30 or $90 \mathrm{mg}$ of BACE inhibitor LY2811376 administered to healthy human subjects resulted in significant biomarker changes in plasma and CSF. $A$, Plasma concentrations of $A \beta_{1-40}$ decreased in a dose-dependent manner, with the $90 \mathrm{mg}$ dose producing an observed mean nadir of $-80.0 \%$. B, C, CSF concentrations of $A \beta_{1-40}$ and $A \beta_{1-42}$ significantly decreased relative to placebo, with a $90 \mathrm{mg}$ dose producing observed mean nadirs of -58.0 and $-58.1 \%$, respectively. In placebo-treated subjects, CSF concentrations of $A \beta_{1-40}$ and $A \beta_{1-42}$ increased over time without a return to baseline, suggesting a procedural phenomenon rather than diurnal effect. The average predose baseline CSF concentrations of $A \beta_{1-40}$ and $A \beta_{1-42}$ were $\sim 5300$ and $650 \mathrm{pg} / \mathrm{ml}$, respectively. $\boldsymbol{D}, \boldsymbol{E}$, Administration of LY 2811376 resulted in decreases in CSF concentration of SAPP $\beta$ and increases in CSF concentration of SAPP $\alpha$, providing direct evidence of the mechanism of action of LY2811376 in the CNS of man. Data are presented as mean \pm SD and $n=10$ for all graphs.

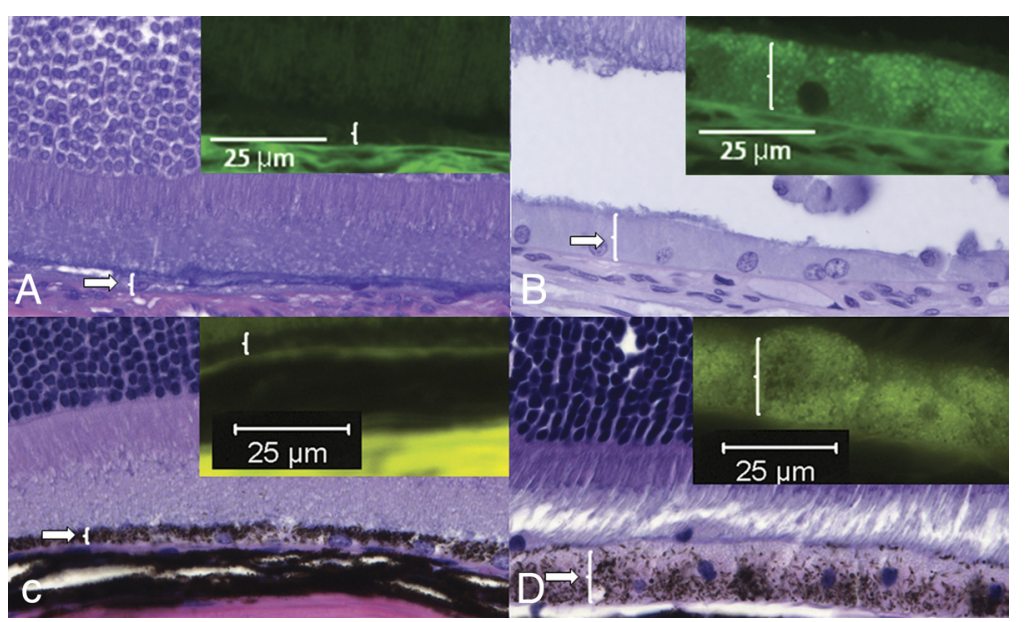

Figure 6. LY2811376-related changes in the retinal epithelium of Sprague Dawley [Crl:CD(SD)] rats (top) and BACE1 ${ }^{-/-} \mathrm{knock}^{-0 u t}$ (BACE1tm1Pcw) mice (bottom). Retinas from the vehicle-treated rats ( $\boldsymbol{A}$ ) and mice (C) werenormal. Retinal epithelial cells from LY2811376-treated rats $(\boldsymbol{B})$ and mice $(\boldsymbol{D})$ were enlarged and distended with autofluorescent granular material (insets). The retinal epithelial layer is labeled with arrow and/or bracket. Note the brown pigment granules within the retinal epithelial layer and underlying choroid, which are a normal feature of the eye from this strain of pigmented mouse $(\boldsymbol{C}, \boldsymbol{D})$ but absent in the eye from the albino Sprague Dawley rat $(\boldsymbol{A}, \boldsymbol{B})$. Additionally, the bright yellow-green zone in the bottom right of the inset for $C$ is attributable to autofluorescence of the scleral collagen, a normal structure that is not included in the insets for $\boldsymbol{A}, \boldsymbol{B}$, or $\boldsymbol{D}$. H\&E stain. Insets are H\&E-stained sections viewed with epifluorescence.

as off-target idiosyncratic toxicity profiles to establish an adequate safety margin. Once established, adequately powered long-term clinical trials of similar compounds with comparable PD responses in appropriate populations will be required. 


\section{References}

Bateman RJ, Wen G, Morris JC, Holtzman DM (2007) Fluctuations of CSF amyloid- $\beta$ levels. Neurology 68:666-669.

Bateman RJ, Siemers ER, Mawuenyega KG, Wen G, Browning KR, Sigurdson WC, Yarasheski KE, Friedrich SW, Demattos RB, May PC, Paul SM, Holtzman DM (2009) A gamma-secretase inhibitor decreases amyloidbeta production in the central nervous system. Ann Neurol 66:48 -54.

Brackenbury WJ, Isom LL (2008) Voltage-gated $\mathrm{Na}^{+}$channels: potential for $\beta$ subunits as therapeutic targets. Expert Opin Ther Targets 12:1191-1203.

Cai H, Wang Y, McCarthy D, Wen H, Borchelt DR, Price DL, Wong PC (2001) BACE1 is the major beta-secretase for generation of Abeta peptides by neurons. Nat Neurosci 4:233-234.

Citron M, Oltersdorf T, Haass C, McConlogue L, Hung AY, Seubert P, VigoPelfrey C, Lieberburg I, Selkoe DJ (1992) Mutation of the $\beta$-amyloid precursor protein in familial Alzheimer's disease increases $\beta$-protein production. Nature 360:672-674.

Collaborative Computational Project, Number 4 (1994) The CCP4 suite: programs for protein crystallography. Acta Crystallogr D Biol Crystallogr 50:760-763.

Dovey HF, John V, Anderson JP, Chen LZ, de Saint Andrieu P, Fang LY, Freedman SB, Folmer B, Goldbach E, Holsztynska EJ, Hu KL, JohnsonWood KL, Kennedy SL, Kholodenko D, Knops JE, Latimer LH, Lee M, Liao Z, Lieberburg IM, Motter RN, et al (2001) Functional gammasecretase inhibitors reduce beta-amyloid peptide levels in brain. J Neurochem 76:173-181.

Emsley P, Lohkamp B, Scott WG, Cowtan K (2010) Features and development of Coot. Acta Crystallogr D Biol Crystallogr 66:486-501.

Erlanson DA, McDowell RS, O'Brien T (2004) Fragment-based drug discovery. J Med Chem 47:3463-3482.

Evin G, Zhu A, Holsinger RM, Masters CL, Li QX (2003) Proteolytic processing of the Alzheimer's disease amyloid precursor protein in brain and platelets. J Neurosci Res 74:386-392.

Games D, Adams D, Alessandrini R, Barbour R, Berthelette P, Blackwell C, Carr T, Clemens J, Donaldson T, Gillespie F (1995) Alzheimer-type neuropathology in transgenic mice overexpressing V717F $\beta$-amyloid precursor protein. Nature 373:523-527.

Hardy J, Selkoe DJ (2002) The amyloid hypothesis of Alzheimer's disease: progress and problems on the road to therapeutics. Science 297:353-356.

Hitt BD, Jaramillo TC, Chetkovich DM, Vassar R (2010) BACE1-/- mice exhibit seizure activity that does not correlate with sodium channel level or axonal localization. Mol Neurodegener 5:31.

Hong L, Koelsch G, Lin X, Wu S, Terzyan S, Ghosh AK, Zhang XC, Tang J (2000) Structure of the protease domain of memapsin 2 (beta-secretase) complexed with inhibitor. Science 290:150-153.

Hopkins AL, Groom CR, Alex A (2004) Ligand efficiency: a useful metric for lead selection. Drug Discovery Today 9:430-431.

Hu X, Hicks CW, He W, Wong P, Macklin WB, Trapp BD, Yan R (2006) Bacel modulates myelination in the central and peripheral nervous system. Nat Neurosci 9:1520-1525.

Hu X, He W, Diaconu C, Tang X, Kidd GJ, Macklin WB, Trapp BD, Yan R (2008) Genetic deletion of BACE1 in mice affects remyelination of sciatic nerves. FASEB J 22:2970-2980.

Hussain I, Powell D, Howlett DR, Tew DG, Meek TD, Chapman C, Gloger IS, Murphy KE, Southan CD, Ryan DM, Smith TS, Simmons DL, Walsh FS, Dingwall C, Christie G (1999) Identification of a novel aspartic protease (Asp 2) as beta-secretase. Mol Cell Neurosci 14:419-427.

Hussain I, Hawkins J, Harrison D, Hille C, Wayne G, Cutler L, Buck T, Walter D, Demont E, Howes C, Naylor A, Jeffrey P, Gonzalez MI, Dingwall C, Michel A, Redshaw S, Davis JB (2007) Oral administration of a potent and selective non-peptidic BACE-1 inhibitor decreases beta-cleavage of amyloid precursor protein and amyloid-beta production in vivo. J Neurochem 100:802-809.

Johnson-Wood K, Lee M, Motter R, Hu K, Gordon G, Barbour R, Khan K, Gordon M, Tan H, Games D, Lieberburg I, Schenk D, Seubert P, McConlogue L (1997) Amyloid precursor protein processing and A $\beta 42$ deposition in a transgenic mouse model of Alzheimer disease. Proc Natl Acad Sci USA 94:1550-1555.

Kim DY, Carey BW, Wang H, Ingano LA, Binshtok AM, Wertz MH, Pettingell WH, He P, Lee VM, Woolf CJ, Kovacs DM (2007) BACE1 regulates voltage-gated sodium channels and neuronal activity. Nat Cell Biol 9:755-764.
Laird FM, Cai H, Savonenko AV, Farah MH, He K, Melnikova T, Wen H, Chiang HC, Xu G, Koliatsos VE, Borchelt DR, Price DL, Lee HK, Wong PC (2005) BACE1, a major determinant of selective vulnerability of the brain to amyloid- $\beta$ amyloidogenesis, is essential for cognitive, emotional, and synaptic functions. J Neurosci 25:11693-11709.

Lin X, Koelsch G, Wu S, Downs D, Dashti A, Tang J (2000) Human aspartic protease memapsin 2 cleaves the beta-secretase site of beta-amyloid precursor protein. Proc Natl Acad Sci USA 97:1456-1460.

Luo Y, Bolon B, Kahn S, Bennett BD, Babu-Khan S, Denis P, Fan W, Kha H, Zhang J, Gong Y, Martin L, Louis JC, Yan Q, Richards WG, Citron M, Vassar R (2001) Mice deficient in BACE1, the Alzheimer's betasecretase, have normal phenotype and abolished beta-amyloid generation. Nat Neurosci 4:231-232.

Malamas MS, Robichaud A, Erdei J, Quagliato D, Solvibile W, Zhou P, Morris K, Turner J, Wagner E, Fan K, Olland A, Jacobsen S, Reinhart P, Riddell D, Pangalos M (2010) Design and synthesis of aminohydantoins as potent and selective human beta-secretase (BACE1) inhibitors with enhanced brain permeability. Bioorg Med Chem Lett 20:6597-6605.

Meredith JE Jr, Thompson LA, Toyn JH, Marcin L, Barten DM, Marcinkeviciene J, Kopcho L, Kim Y, Lin A, Guss V, Burton C, Iben L, Polson C, Cantone J, Ford M, Drexler D, Fiedler T, Lentz KA, Grace JE Jr, Kolb J, et al. (2008) P-glycoprotein efflux and other factors limit brain amyloid beta reduction by beta-site amyloid precursor protein-cleaving enzyme 1 inhibitors in mice. J Pharmacol Exp Ther 326:502-513.

Michailov GV, Sereda MW, Brinkmann BG, Fischer TM, Haug B, Birchmeier C, Role L, Lai C, Schwab MH, Nave KA (2004) Axonal neuregulin-1 regulates myelin sheath thickness. Science 304:700-703.

Ohashi K, Osuga J, Tozawa R, Kitamine T, Yagyu H, Sekiya M, Tomita S, Okazaki H, Tamura Y, Yahagi N, Iizuka Y, Harada K, Gotoda T, Shimano H, Yamada N, Ishibashi S (2003) Early embryonic lethality caused by targeted disruption of the 3-hydroxy-3-methylglutaryl-CoA reductase gene. J Biol Chem 278:42936-42941.

Rajendran L, Schneider A, Schlechtingen G, Weidlich S, Ries J, Braxmeier T, Schwille P, Schulz JB, Schroeder C, Simons M, Jennings G, Knölker HJ, Simons K (2008) Efficient inhibition of the Alzheimer's disease betasecretase by membrane targeting. Science 320:520-523.

Roberds SL, Anderson J, Basi G, Bienkowski MJ, Branstetter DG, Chen KS, Freedman SB, Frigon NL, Games D, Hu K, Johnson-Wood K, Kappenman KE, Kawabe TT, Kola I, Kuehn R, Lee M, Liu W, Motter R, Nichols NF, Power M, et al. (2001) BACE knockout mice are healthy despite lacking the primary beta-secretase activity in brain: implications for Alzheimer's disease therapeutics. Hum Mol Genet 10:1317-1324.

Sankaranarayanan S, Price EA, Wu G, Crouthamel MC, Shi XP, Tugusheva K, Tyler KX, Kahana J, Ellis J, Jin L, Steele T, Stachel S, Coburn C, Simon AJ (2008) In vivo beta-secretase 1 inhibition leads to brain Abeta lowering and increased alpha-secretase processing of amyloid precursor protein without effect on neuregulin-1. J Pharmacol Exp Ther 324:957-969.

Sankaranarayanan S, Holahan MA, Colussi D, Crouthamel MC, Devanarayan V, Ellis J, Espeseth A, Gates AT, Graham SL, Gregro AR, Hazuda D, Hochman JH, Holloway K, Jin L, Kahana J, Lai MT, Lineberger J, McGaughey G, Moore KP, Nantermet P, et al. (2009) First demonstration of cerebrospinal fluid and plasma A beta lowering with oral administration of a beta-site amyloid precursor protein-cleaving enzyme 1 inhibitor in nonhuman primates. J Pharmacol Exp Ther 328:131-140.

Sharma KK, Ralhan NK, Narang KS (1963) Pyrimidobenzothiazine derivatives. II. The condensation of isothiocyano ketones and aryl amines. J Org Chem 28:740-742.

Simmons J (2003) The $\$ 10$ billion pill. In: Fortune magazine, January 20.

Sinha S, Anderson JP, Barbour R, Basi GS, Caccavello R, Davis D, Doan M, Dovey HF, Frigon N, Hong J, Jacobson-Croak K, Jewett N, Keim P, Knops J, Lieberburg I, Power M, Tan H, Tatsuno G, Tung J, Schenk D, et al. (1999) Purification and cloning of amyloid precursor protein betasecretase from human brain. Nature 402:537-540.

Stachel SJ (2009) Progress toward the development of a viable BACE-1 inhibitor. Drug Dev Res 70:101-110.

Strobel G (2008) Keystone drug news: CoMentis BACE inhibitor debuts. In: Alzheimer's Research Forum. Available at http://www.alzforum.org/new/ detail.asp?id $=1790$.

Vassar R, Bennett BD, Babu-Khan S, Kahn S, Mendiaz EA, Denis P, Teplow DB, Ross S, Amarante P, Loeloff R, Luo Y, Fisher S, Fuller J, Edenson S, 
Lile J, Jarosinski MA, Biere AL, Curran E, Burgess T, Louis JC, et al. (1999) Beta-secretase cleavage of Alzheimer's amyloid precursor protein by the transmembrane aspartic protease BACE. Science 286:735-741.

Willem M, Garratt AN, Novak B, Citron M, Kaufmann S, Rittger A, DeStrooper B, Saftig P, Birchmeier C, Haass C (2006) Control of peripheral nerve myelination by the beta-secretase BACE1. Science 314: $664-666$.

Wong HK, Sakurai T, Oyama F, Kaneko K, Wada K, Miyazaki H, Kurosawa M, De Strooper B, Saftig P, Nukina N (2005) $\beta$ subunits of voltage-gated sodium channels are novel substrates of $\beta$-site amyloid precursor proteincleaving enzyme (BACE1) and $\gamma$-secretase. J Biol Chem 280:23009-23017.

Yan R, Bienkowski MJ, Shuck ME, Miao H, Tory MC, Pauley AM, Brashier JR, Stratman NC, Mathews WR, Buhl AE, Carter DB, Tomasselli AG, Parodi LA, Heinrikson RL, Gurney ME (1999) Membrane-anchored as- partyl protease with Alzheimer's disease beta-secretase activity. Nature 402:533-537.

Yang HC, Chai X, Mosior M, Kohn W, Boggs LN, Erickson JA, McClure DB, Yeh WK, Zhang L, Gonzalez-DeWhitt P, Mayer JP, Martin JA, Hu J, Chen SH, Bueno AB, Little SP, McCarthy JR, May PC (2004) Biochemical and kinetic characterization of BACE1: investigation into the putative species-specificity for beta- and beta' -cleavage sites by human and murine BACE1. J Neurochem 91:1249-1259.

Younkin SG (1995) Evidence that A beta 42 is the real culprit in Alzheimer's disease. Ann Neurol 37:287-288.

Zhu Y, Xiao K, Ma L, Xiong B, Fu Y, Yu H, Wang W, Wang X, Hu D, Peng H, Li J, Gong Q, Chai Q, Tang X, Zhang H, Li J, Shen J (2009) Design, synthesis and biological evaluation of novel dual inhibitors of acetylcholinesterase and beta-secretase. Bioorg Med Chem 17:1600-1613. 